др Александар Раковић

Институт за новију $\quad$ 78.067.26(497.1)"1956/1968" историју Србије, Београд https://doi.org/10.18485/ai_san_o_gradu.2018.ch18

\title{
РОКЕНРОЛ У СОЦИЈАЛИСТИЧКОЈ ЈУГОСЛАВИЈИ: ОД ЗАБАВЕ ГРАДСКЕ ОМЛАДИНЕ ДО НАЦИОНАЛНЕ КУЛТУРЕ ${ }^{1}$
}

У посматраном периоду од 1956. до 1981. рад приказује еволуцију рокенрола у Југославији од забаве градске омладине, преко омладинске поткултуре и омладинске културе, до националне културе.

Кључне речи: Рокенрол, Југославија, социјализам, омладина, култура.

Током претходних десетак година истражио сам десетине хиљада страница архивске грађе и домаће штампе, као и више стотина домаћих и страних књига и радова који се баве југословенским и иностраним рокенролом, омладинским темама и поткултурама, међународним културним и политичким односима, феноменима популарне културе.

Сазнања и закључке до којих сам дошао досад сам објавио у својој књизи Рокенрол у Јуіоставији 1956-1968. Изазов социјалистиччком gрушитву (Београд: Архипелаг, 2011, 642 стране) и својим радовима објављеним у научним часописима и зборницима:

$1 \otimes$ Рад је настао у оквиру пројекта „Срби и Србија у југословенском и међународном контексту: унутрашњи развитак и положај у европској/светској заједници“ (47027) који финансира Министарство просвете и науке Републике Србије. 
„Бит мода, рокенрол и генерацијски сукоб у Југосла-

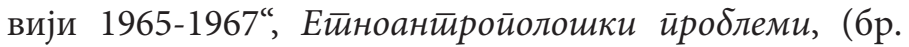
3, Београд 2011, 745-762); „Савез социјалистичке омладине Југославије и Музичка омладина Југославије у спору око рокенрола (1971-1981)“, Токови иситорије (бр. 3, Београд 2012, 159-189); „Југословенска државна политика и западна популарна музика (џез и рокенрол) током педесетих и шездесетих година 20. века“, Кулим $y$ ре у gијалоїу. Комуникација и кулитурни уйицаји (књ. 4 , Зборник радова међународне научне конференције „Културе у дијалогу“, Београд: Филолошки факултет 2013, 91-110); „Џон Ленон, левичарски активизам и југословенски социјализам“, Токови истиорије (бр. 3, Београд 2013, 251-265); „Употреба рокенрола у рату СР Југославије и НАТО пакта (1999): са освртом на претходно обликовање српске контракултуре деведесетих и потоње последице за популарну музику у Србији“, Кулйура йолиса (бр. 28 , Нови Сад 2015, 387-402); „Bijelo dugme Concert in Hajdučka česma in Belgrade (1977): Social Event of the Utmost Importance and Recognition of a Unique Phenomenon“, Токови истиорије (бр. 3/2015, Београд 2016, 107-133); „Југословенска мека дипломатија према Совјетском Савезу на примеру забавне музике током шездесетих година 20. века“, Србија и Русија 1814-1914-2014 (Зборник радова међународног научног скупа „Србија и Русија 1814-1914-2014“, (Београд: Српска академија наука и уметности 2016, 331-344); „Мјузикл Коса у Атељеу 212 (1969-1973)“, Токови исииорије (бр. 2, Београд 2017, 85-114).

У штампи су и моји радови „Рок опера Исус Христос суперстар у Атељеу 212 (1972-1973)“ који ће 2018. бити објављен у Токовима исииорије и „Развој рокенрола у социјалистичкој Југославији и културно-политички оквир (1956-1991): са освртом на српске и пра- 
вославне мотиве у југословенском рокенролу“ који ће такође бити објављен 2018. у зборнику Истиорија јеgне уйойије: 100 іолина сииварағь Јуіоставије издавача Катена мунди.

У овом раду „Рокенрол у социјалистичкој Југославији: од забаве градске омладине до националне културе“ први пут на једном месту представљам сазнања о путу који је југословенски рокенрол прешао од забаве градске омладине до националне културе.

Рокенрол је највећа друштвена и културна револуција 20. века, музика и култура која је прескочила историјске баријере: расне, етничке, језичке, политичке, верске и социјалне. На америчком Југу уз рокенрол је уклањана расна сегрегација. На даљем путу падале су ниже препреке у Западној Европи, а потом и оне више у Источној Европи. Кроз земље хришћанске цивилизације рокенрол је наставио пут ка исламским и далекоисточним световима. И све се то догодило од средине педесетих до почетка шездесетих година 20. века.

За свега неколико година урбана омладина широм земљине кугле слушала је исту музику и плесала уз исти ритам. Током првих петнаест година развитка (1954-1969) рокенрол на Западу је прошао еволуцију од омладинске поткултуре, преко омладинске културе ка контракултури и, на крају, ка пуној култури. Рокенрол је, дакле, дефинисан као музика и култура која је доминирала и у наредне две деценије. Друга половина 20. века се не може разумети без схватања те музике и културе, посебно ако се има у виду да је рокенрол изгубио глобалну друштвену важност с падом социјалистичког блока (1991). Рокенрол је тиме подвукао свој значај као звук и слух Хладног рата.

Југословенској јавности је била позната поли- 
тичка снага коју је носио рокенрол. У другој половини педесетих се на примеру Елвиса Прислија показало да амерички председнички кандидати праве калкулацију да ли им Елвисова подршка у неком смислу може помоћи. Подршка коју су Битлси дали лабуристима водила је ову странку до победе на страначким изборима и формирања владе. Сличних примера било је и другде на Западу. Хипи контракултура је преко свог политичног крила ковала планове да збаци америчког председника Ричарда Никсона.

Неколико година након стварања социјалистичке Југославије 1945. у земљи је доминирао совјетски културни концепт. Џез је у потпуности био потиснут на друштвену маргину и ходао је по трњу све до окончања сукоба са Информбироом (1948-1953) када му је Комунистичка партија Југославије дала простор због најширег отварања југословенске државне политике према Западу. С тим нису могли да се помире високи музички уметници јер су џез сматрали дилетантском музиком која залуђује омладину и одводи је од стицања префињеног музичког укуса.

Тако је 1957. у штампи поведена расправа о квалитету џеза и забавне музике. Било је мишљења да џез Југословене повезује са читавим светом, а да југословенска забавна музика, којој је требало дати препознатљив карактер, има намену унутрашњег кохезионог фактора. Стога је 1958. из партије сугерисано композиторима, аранжерима, музичарима и певачима да је потребан озбиљан приступ стварању општејугословенске естраде. Док је југословенски џез до средине шездесетих посрнуо, што због одлазака џезера у иностранство што због налета рокенрола, југословенска забавна музика се протежирано развијала.

Западни видови забаве прихваћени су, интегри- 
сани и примењени у Југославији у свим могућим видовима који нису сметали партијској идеологији. Jугословенско друштво је путем деловања иностраних културних центара, филма и забавне штампе било преплављено западним попкултурним садржајима. Велика популарност културних центара Сједињених Америчких Држава и Велике Британије, а током шездесетих и биоскопски репертоар (са бар 75\% западних филмова) и странице забавне штампе (са чак до 98\% садржаја западног порекла) подвукли су интересовање Југословена за западне забаве и теме.

Млади Југословени су од средине педесетих година 20. века стицали сазнања о рокенрол музици и плесу. Југословенска штампа је од почетних веома негативно интонираних текстова 1956. године, према којима је рокенрол сматран декадентном музиком, до краја те деценије мењала начин писања. Из године у годину текстови у штампи су постајали све афирмативнији по рокерску музику и плес. Преко писања југословенских новина уочава се како је у Југославији тада постојала свест да је музика електричних гитара, које год име да је носила у неком временском периоду, јединствена појава, те да су Радио Луксембург, војне и пиратске радио станице шириле звуке рокенрола преко блоковских граница. Међутим, до конца педесетих партијски аналитичари се нису стручно бавили анализом рокенрола као појаве која је све више обузимала југословенску омладину.

Афроамерички џез музичари били су у другој половини педесетих и током шездесетих радо виђени гости на југословенским сценама јер је и тим путем потврђивана југословенска политика антисегрегационизма, деколонизације, пацифизма и несврстаности. С тим 
у вези, у југословенској јавности је већ на прелому педесетих и шездесетих било јасно да ће рокенрол наставити путем који је већ утирао џез: да ће превазилазити баријере света подељеног на непомирљиве блокове, политичке и верске идеологије, колонијалне господаре и антиколонијалне покрете.

Рокенрол је друштвене баријере прескакао и у Југославији, али се чини да су, на пример, крајем педесетих и почетком шездесетих деца из старих београдских породица и деца партијских функционера истоветну музику још увек слушала у засебним друштвима. Тих година рокенрол је схватан пре као плес него као музика, а рокенрол плес је тада био најпопуларнији вид забаве на београдским и загребачким игранкама. О томе је чак извештавала и америчка штампа.

Први рокенрол наступ у Југославији био је у фебруару 1957. када је нову музику на Коларцу у Београду извео Стјепан Џими Станић. Затим су од фебруара 1958. на београдским игранкама следили вишегодишњи култни наступи рокенрол гитаристе Милета Лојпура, с врхунцем на кошаркашким теренима Црвене звезде када је, почетком шездесетих, нова играчка манија Југословена постао твист. Тај нови рокенрол плес освојио је југословенску градску омладину. Оба рокенрол плеса - рокенрол и твист - су била толико масовно прихваћена да им на прелому педесетих и почетком шездесетих више није било конкуренције. Крај педесетих и почетак шездесетих у Југославији бележи и прве изричито опредељене рокере који су песмом и свирком остајали утемељени у рокенролу.

До визне либерализације 1961. пионирску улогу у доношењу рокенрол плоча у земљу имали су шахисти и спортисти, посебно шахисти Светозар Глигорић и Никола Караклајић, кошаркаш Радивој Кораћ и фуд- 
балер Драгослав Шекуларац. Када је о шахистима реч, посебно је њихов углед сугерисао скептицима како има простора да се промисли о улози рокенрола у југословенском друштву.

Чим је стигао на југословенске игранке у другој половини педесетих, рокенрол је „оптужен“ да плесом превише истиче сексуалност. Скривени од очију јавности млади су на журевима уз музику и пригушено светло кренули с првим слободнијим додирима. Журеви су за родитеље били главни проблем, а рокенрол је уз њих ишао као потпроблем. Међутим, почетком шездесетих девојке су све слободније говориле да желе да имају сексуалне односе пре брака. Истовремено, у партији је превладало мишљење да су упоређивања предратног и послератног морала потпуно погрешна. Из године у годину границе су померане. Освајање сексуалних слобода у Југославији ишло је својим током у складу са истим појавама на Западу. Партија то није реметила јер није сматрала да се то коси са социјалистичким моралом.

Југословенска штампа и радио су до краја шездесетих у највећој мери покривали рокенрол новитете у свету па су тиме продубљивана сазнања о рокенролу као глобалном феномену. Рокери су прешли пут од споредног улаза на естрадну сцену (1963), као пратећи састави најпопуларнијим певачима, до масовних гитаријада бит бендова $(1966,1967)$ и професионализације рокенрол састава. Југословенски рокенрол је током шездесетих ишао сасвим у корак са светским рокенрол трендовима, али са озбиљним недостатком јер су се састави ређе опредељивали за сопствене композиције.

Током шездесетих социјалне баријере слушалаца рокенрола, бар када је о музици реч, углавном су превазиђене. Упркос томе, оновремена испитивања Савеза 
комуниста су показала да је било разлика у поимању рокенрола међу гимназијском и радничком омладином: прва је о рокенролу знала више, а друга га је масовније слушала. Однос југословенске јавности према рокенролу је након 1966. године, с неким изузецима, углавном био позитиван. До половине шездесетих рокенрол је постао толико масован да су га партијски аналитичари ставили у оквир културног покрета и описали га као појаву која није пролазна.

Прва велика београдска гитаријада (1966), масовна посета и понашање младих, као нагазна мина изазвали су полемике на разним стручним и политичким нивоима. Тиме је овај догађај постао преломни моменат у историји југословенског друштва. У структурама средњег нивоа у Савезу комуниста било је мишљења да је та београдска гитаријада бацила рукавицу у лице југословенском социјализму. Међутим, партијски аналитичари и омладинска организација (тада Народна омладина Југославије, па потом Савез омладине Југославије и Савез социјалистичке омладине Југославије) су то негирали. Државни и партијски врх су прихватили став да се рокенрол не коси са социјалистичким вредностима. Од 1966. рокенрол састави су сваке године свирали пред Титом за Дан младости у Дому омладине Београда. Набујали југословенски рокенрол добио је форму музике младих Југословена - омладинске поткултуре с карактеристичном музиком, модом (дугим косама младића, кратким сукњама девојака, шареном одећом) и друштвеним животом кроз клубове, часописе, радио и телевизијске емисије који су још више набујали у наредним деценијама.

Требало је, на концу, убедити старе и прекаљене борце, партизане, да су дугокоси младићи верни теко- 
винама револуције. Дуга коса неких рокерских састава попут београдских Силуета и све више љубитеља рокенрола који су кренули пут те моде, будила је код револуционара асоцијације према четницима. Стога је почетком 1967. у јавности отворена полемика о односу дугокосих младића према социјалистичкој револуцији. Поклоници рокенрола су поручили, односно тако је штампа писала, да је револуција за њих светиња али и да више не желе да слушају непрестане оптужбе да су непримерни омладинци јер им је музика важнија од славне прошлости. Врата Савеза комуниста више нису била затворена за дугокосе младиће. У партијским анализама је изнова подвлачено да је југословенска омладина примерна и социјалистичка, без обзира на то што је била окренута западној популарној култури.

Југословенска штампа, стручњаци и партијски аналитичари су посебно обраћали пажњу на контракултурне појаве у Сједињеним Америчким Државама: битнике, антиратну омладину (студентску нову левицу) и хипике. Контракултура се залагала за: пацифизам, антиколонијализам, антисегрегацију, једнакост, била је против потрошачког капиталистичког друштва и заступала је идеје левице. У Савезу комуниста је 1968. примећено да би хипици у кохезији са идејама нове левице могли имати револуционарни потенцијал на тлу Сједињених Америчких Држава.

Стога је простор за хипи идеје у Југославији био лако освојив. Док су се амерички политични хипици огорчено борили против естаблишмента, југословенски хипици су истовремено снимали неке од најлепших песама о револуцији и социјализму. Пошто је југословенски пут несврставања имао углавном сличне циљеве као и хипи покрет, овакав вид компромиса рокенрола и партије није био неприродан. Због тога, међутим, 
хипици у Југославији никада нису били контракултура. Као што је 24. маја 1966. дао легитимитет рокенролу тиме што су београдске Елипсе наступиле пред њим, југословенски председник Јосип Броз Тито је 24. маја 1969. преко мјузикла Коса Атељеа 212 исту врсту легитимитета пружио хипи утицајима на југословенску омладину. Рокенрол је до краја шездесетих спознат као југословенска омладинска култура. Иначе, лидери хипика Џером Рагни (коаутор мјузикла Коса) и Џон Ленон исказивали су поштовање према југословенском социјалистичком путу. Приликом боравка у Београду 1969. на једном од извођења Косе у Атељеу 212, Рагни је за Борбу (22. јун 1969) говорио похвално о Југославији и њеној омладини која нема против чега да се буни. Џон Ленон је 1971. за Вјесник у сријеgу (4. август 1971) казао да је комуниста и да му се најближим чини југословенски самоуправни социјализам.

Историјски ток је показао да су Савез комуниста и омладинска организација на сваки изазов одговорили пружањем руке. Компромисом су добили и партија и рокенрол (омладина). Партија је рокенролу омогућила несметан развој, а рокенрол је партији задржао социјалистичку омладину којој су социјалне и етничке поделе биле све мање важне. Рокенрол се показао као кохезиони фактор у општејугословенским оквирима, трагом који је раније дат забавној музици. Притом, рокенрол не само да је нашао место у југословенском попкултурном моделу, већ је постао његов носилац све до разбијања социјалистичке Југославије.

Јединство омладине било је ослабљено подршком дела младих у Хрватској Масовном покрету (1970-1971) када је код хрватских националиста у партијским редовима и хрватских клерикалаца дошло до неочекиваног 
али истовременог ослонца на популарну културу и рокенрол у раду са хрватском омладином. Да би сузбијали хрватски национализам (и сваки други национализам), у партијском врху су постављене смернице да омладини кроз образовање треба дати више марксистичке доктрине што је постало део образовног система у Југославији седамдесетих. Рокенрол је требало дубље утврдити као спону међу младим Југословенима.

Када је о музичком образовању реч, ваннаставне активности је организовала Музичка омладина Југославије (односно њене републичке и градске организације) која је младима нудила само образовање у пољима високе музичке уметности. Међу најважнијим носиоцима сећања на социјалистичку револуцију и Титово дело били су рокенрол састави, на првом месту Корни група и Бијело дугме. Рокери су за себе захтевали више друштвене ангажованости и слободарског утицаја. Стотине хиљада младих Југословена слушало je, поред уобичајених рокенрол песама, и све више слободарских порука које су преко текстова или слогана нудили домаћи састави.

У Савезу комуниста Југославије и Савезу социјалистичке омладине Југославије спознали су до половине седамдесетих да се ваннаставно социјалистичко образовање омладине најпре може одвијати преко рокенрола и с тим у вези омладинска организација је затражила од Музичке омладине да рокенрол уврсти у програм образовања. Музичка омладина није прихватила сугестије, а потом се суочила са претњама да би, што милом што силом, 1981. прихватила рокенрол као образовно поље рада са југословенском омладином.

Претходно, с тим у вези, два водећа дневна листа у Београду и Загребу, Полийика и Вјесник, „признали“ су у лето 1977. југословенски рокенрол за културу јер 
се о тој музици писало на страницама које су дотад биле резервисане за високу културу. Савез социјалистичке омладине, штампа омладинске организације али и најважнија дневно-политичка штампа су до краја седамдесетих сматрали да је рокенрол „тотална култура“ и „права, нова култура“ у Југославији. Тиме што је озбиљна југословенска штампа прихватила да је рокенрол култура, а не само омладинска култура, и тиме што је Музичка омладина Југославије на концу прихватила да рокенрол постане и образовна активност, рокенрол култура је на читавом југословенском простору до 1981. досегла вид националне културе.

Кроз улогу омладине као једног од стубова југословенске државе (Тито-партија-омладина-армија) рокенрол се високо позиционирао у самоуправном друштву до самог краја Социјалистичке Федеративне Републике Југославије. Прешао је пут од забаве градске омладине, преко омладинске поткултуре и омладинске културе, до националне односно пуне културе. Стога има мишљења да је рокенрол продукција грамофонских плоча у Југославији била, по глави становника, трећа у свету: после Сједињених Америчких Држава и Велике Британије. Рокенрол у социјалистичкој Југославији никада није постао контракултура, већ се као такав формирао тек у Савезној Републици Југославији током судара омладине са властима на чијем је челу био Слободан Милошевић. 
Aleksandar Raković, PhD

\section{ROCK AND ROLL IN SOCIALIST FEDERAL REPUBLIC OF YUGOSLAVIA: \\ FROM THE YOUTH ENTERTAINMENT IN THE \\ URBAN AREAS TO THE NATIONAL CULTURE}

The paper depicts the social evolution that Yugoslav rock'n'roll passed from the initial youth entertainment in the urban areas of the late 1950s and the first half of the sixties of the 20th century through the acceptance of rock'n'roll as a kind of culture of a suitable socialist youth in the second half of the sixties and the first half of the seventies to the formation of rock and roll as a national culture in the entire area of The Socialist Federal Republic of Yugoslavia from the second half of the seventies to the beginning of the nineties of the 20th century.

Key words: rock and roll, youth, socialism, Yugoslavia, culture. 